\title{
Readiness of teachers for designing a humanistically oriented educational environment of a university
}

\author{
Asya Berberyan* \\ Russian-Armenian University, Yerevan, Armenia
}

\begin{abstract}
In the current article, the assumptions are proposed based on the analysis of theoretical sources and on the perspective of considering the semantic field ofa humanistically oriented educational environment as a complex of elements that reveal the willingness and humanistic position of subjects. The research hypothesis lies in the assumption that such components of the "Self-concept" as creativity, intentionality, authenticity, and the desire for self-actualization contribute to the formation of teachers'readiness for designing a humanistically oriented educational environment. The purpose of the study is to study the components of teachers' readiness for constructing a humanistically oriented educational environment. The results of the experimental study testified to the expansion of semantic boundaries and awareness of the subjective significance of higher values, as well as to the willingness of teachers to design a humanistically oriented educational environment.
\end{abstract}

\section{Introduction}

Personal and professional development is largely determined by the characteristics of the personal and professional space. The space of the university environment associated with educational activities or preparation for this process is organized into educational and professional space, which is characterized by a special structure of formed relations with the social environment, with the organization of time, educational space, material living standards, regulated by the quality of work performed; the direction of self-awareness, filled with professionally necessary information, structured in the context of professional methods of interpretation and generalization, providing "distribution" and understanding of environmental events through appropriate professional orientation of actions, which leads to the formation of a certain "image of the world". A university educational space acts as a significant professional space. Modern requirements for the professional activity of a university teacher determine the need for innovative transformations and the educational space of a university. The essence of designing the educational environment of a university is, first of all, in constructing a model aimed at professional development of a person in accordance with universal and national interests and values $[1,2,3]$.

\footnotetext{
${ }^{*}$ Corresponding author: aspsy@inbox.ru
} 
The relevance of the problem is determined by the following fundamental provisions:

- in the current socio-political and economic conditions of global social development, the humanization of the entire educational process acts as an important prerequisite and a scientific and practical foundation for the modernization of the higher education system. In this regard, the task is to prepare a specialist, a carrier of values and an existential essence, where professional training is only the face of his unique personality [4];

- the global trend of humanization and humanization of the educational process sets the task of designing and modelling a humanistically oriented environment and studying its impact on the personal and professional development of a specialist $[5,6,7]$. To study this aspect, we consider it appropriate to introduce a triad: environment-humanistic values-personality, which leads to the semantic essence of the triad: cognition -understanding-acceptance. Such factors of the educational environment as the value-semantic nature of the educational space at the university, the value-semantic world of the individual, and the spiritual and moral processes in the university system come to the fore $[8,9]$.

\section{Research hypothesis}

We assume that such components of the "Self-concept" as creativity, intentionality, authenticity, the desire for self-actualization contribute to the formation of teachers' readiness for the design of a humanistically oriented educational environment,

\section{The purpose of the research}

The purpose of the research is to study the components of teachers' readiness for designinga humanistically oriented educational environment.

The study of the problems of the socio-psychological organization of the environmentwas given the closest consideration by Yu.K. Babansky, V.G. Bocharova, B.Z. Vulfov, I.S. Maryenko, M.N. Skatkin, V.A. Slastenin and others.

In our opinion, the semantic field of a humanistically oriented educational environment contains a set of elements that reveal readiness for the humanistic position of subjects. Based on this perspective, we can offer the following provisions:

1. The sense-forming factor of a humanistically oriented environment is the translation of humanistic values of the subjects in the process of educational activities.

2. The design and implementation of the educational process will provide an opportunity to stimulate and give a powerful impetus for personal development.

3. The educational potential of the university, which arises in the context of humanistically oriented values and meanings, is aimed at integrating all the available characteristics of a given environment into a single humanistic space that opens the way to self-development, self-realization and self-actualization.

4. The practical implementation of the conditions is possible due to the following components:

a) designing a model of a humanisticallyoriented educational environment;

b) taking into account universal and ethnocultural values;

c) taking into account the psychological, pedagogical and sociocultural abilities and capabilities of the individual;

d) taking into account innovative technologies to stimulate joint creativity.

Based on modern ideas about the psychological readiness of the specialist to fulfill himself in his professional activity, we consider it possible to include the following components in the structure of the projected model: motivational-value, cognitive, operational-activity, control-corrective, creative components. 
"Authenticity" and "intentionality", which are the systemic qualities of the personality, are identified as significant concepts of the existential-humanistic concept. The concept of authenticity was proposed by C. Rogers [10]. The main attribute of an authentic person the ideal model of the development of a personality is responsibility. In the theoretical constructions of existential-humanistic psychology, responsibility takes place when confidence in one's self, in one's "actualization experience" arises, which is attributable to the "Self-concept", subjective characteristics of the personality. Authenticity, which implies genuineness, congruence and sincerity in relation to oneself, implies reflection, selfreflection of one's "Self", one's activity, the ability to exercise self-control, communication processes.

The concept of intentionality, which is an existential construction, is closely connected with authenticity. Intentionality is the main property of psychic phenomena, acting as their given in consciousness and orientation. In existentialism of intentionality, the inner world of the subject is considered as the main subject of analysis. In the context of our study, we emphasize the importance of this concept as a condition of internal freedom, based on the ability to make responsible decisions in a situation of choice and implement them. In designing and organizing a humanistically oriented educational environment, the teacher has the research task of adequately assessing the value-semantic boundaries of the educational space, taking responsibility for organizing actions and recognizing oneself as a subject of a person who, through actualization experience, goes back to personal and professional growth. And the path to deep meaning, to intentionality, lies through the transformation of the value system. V. Frankl argued that structural changes are the most indicative of a meaningful characterization of intentionality [11]. More rigid, fixed constructs in the process of their change turn into more flexible, intentional. In the theory of J. Kelly, personality constructs represent models that illustrate the features of awareness, "understanding" of reality [12]. They are directly related to the categories of personal growth, development.

In the process of socio-psychological training, the dynamics of "Self-concept" was revealed in accordance with the results of the self-assessment methodology.

\section{Study sample}

We conducted an experiment with teachers from various universities with a total number of 62 people. The average age of teachers is 48.5 years. The average university experience is 18.3 years. In total,the number of women participantsis $61 \%$, men $-39 \%$. The control environment of the indicators was carried out at the beginning of the experiment and at the end of the experiment. The control group was balanced in terms of age, gender, and length of service.

\section{Research Methods}

1. Theoretical analysis and synthesis of scientific literature. 2. In an empirical study, a stating and formative experiment was used with experimental and control groups of respondents.

To identify the willingness of teachers to design a personality-centered educational environment, the following were used: methods of personality constructs by J. Kelly; a questionnaire to determine the level of readiness of a teacher to design a humanistically oriented environment of a university and its role for each educational subject; innovation preparedness questionnaire. Based on the general model of teacher readiness formation, we 
have prepared a private model that reflects the tasks of teachers' preparatory work in stages and the content of their work.

I stage of training sessions - theoretical training. Information and organizational preparation includes a series of classes consisting of conversations, thematic discussions, and round-table meetings held with teachers in an interactive form on a theoretical special course: "Existentially-humanistic concepts of education". For the basis of theoretical preparation, we consider the worldview, humanistic formation of the teacher's personality, associated with the concept of "personal growth", the dynamics of "Self-concept".

II stage. The technologies for managing the development of the teacher's innovative potential consisted of the following forms of interaction: a) training seminars; b) psychological training; c) reflective-analytical conversation; d) methods of reflective analysis of specific situations. Conversations, seminars, and trainings were held as part of the educational project for the humanization of education on the basis of RAU and with the participation of "Acssels".

\section{The results of the study}

\section{$18.3 \%$ had difficulty answering the questionnaire.}

For each of the test subjects, 10 fixed variants of constructs were recorded.

Polarized constructs underwent transformations, which changed their positions to more approximate ones in terms of meaningfulness. This allowed us to make assumptions about a change in some evaluative stereotypes. The results are presented in Table 1.

Table 1. Characteristics of constructs

\begin{tabular}{|l|l|l|l|l|}
\hline \multicolumn{2}{|l|}{ Constructs } & \multicolumn{2}{l|}{ After training } \\
\hline & exp. & $\mathrm{k}$. & exp. & $\mathrm{k}$. \\
\hline «Polar» constructs & 120 & 112 & 96 & 108 \\
\hline «Non-polar» constructs & $\begin{array}{l}40 \\
\mathrm{x}^{2}=5,55, \\
\mathrm{p}<0,02\end{array}$ & 48 & 64 & 52 \\
\hline
\end{tabular}

For each subject, the number of polar constructs can be counted as an index of polarity, or an index of dichotomy. In the works of A. Maslow, the characteristics of a self-actualizing creative personality were singled out; overcoming dichotomy was indicated among the main ones [13]. In our study, we compared the parameters of the dichotomy index with the hierarchy of value orientations and revealed an inverse correlation with the significance of creativity, where $r=0.38$, with $\mathrm{p}<0.05$. According to D.A. Leont'ev, personality constructs are sources of significant meanings [14, p. thirty].

According to parameter II, the formation of the teachers' readiness for designing of a humanistically oriented educational environment in the course of the reforming experiment was revealed by the questionnaire. The results are presented in Table 2.

Table 2. Characteristics of the formation of teachers' readiness for the design of a humanistically oriented educational environment for the period of the experiment.

\begin{tabular}{|c|c|c|}
\hline $\begin{array}{c}\text { Components of } \\
\text { teachers' readiness for }\end{array}$ & $\begin{array}{c}\text { Sections } \\
\text { before and }\end{array}$ & Levels of formation in $\%$ \\
\hline
\end{tabular}




\begin{tabular}{|c|c|c|c|c|c|c|c|}
\hline \multirow{2}{*}{$\begin{array}{l}\text { the design of the } \\
\text { educational } \\
\text { environment }\end{array}$} & \multirow{2}{*}{$\begin{array}{l}\text { after the } \\
\text { experiment }\end{array}$} & \multicolumn{2}{|c|}{ Low } & \multicolumn{2}{|c|}{ Medium } & \multicolumn{2}{|c|}{ High } \\
\hline & & E.gr. & K. gr. & E.gr. & K. gr. & E.gr. & K. gr. \\
\hline \multirow[t]{2}{*}{ I. Motivational value } & before & 49,3 & 80,0 & 29,5 & 19,8 & 0,7 & 0,2 \\
\hline & $\begin{array}{c}\text { after } \\
\text { hefore }\end{array}$ & 15,8 & 53,1 & 28,1 & 35,5 & 56,1 & 11,4 \\
\hline \multirow[t]{2}{*}{ II. Cognitive } & & 850 & 860 & 125 & 120 & 25 & 20 \\
\hline & $\begin{array}{l}\text { before } \\
\text { after }\end{array}$ & 17,0 & 57,5 & 40,6 & 32,4 & 35,3 & 11,9 \\
\hline \multirow[t]{2}{*}{ III. Creative } & $\begin{array}{l}\text { Derore } \\
\text { after }\end{array}$ & 74,7 & 85,9 & 24,9 & 13,4 & 0,4 & 0,7 \\
\hline & $\begin{array}{c}\text { berore } \\
\text { after }\end{array}$ & 36,5 & 45,4 & 38,1 & 43,5 & 25,4 & 11,1 \\
\hline \multirow[t]{2}{*}{$\begin{array}{l}\text { IV. Operational } \\
\text { activity }\end{array}$} & & 80,4 & 80,8 & 19,8 & 19,2 & - & - \\
\hline & & 10,3 & 58,5 & 55,6 & 30,5 & 34,1 & 11,0 \\
\hline \multirow{2}{*}{$\begin{array}{l}\text { V. Assessment and } \\
\text { reflexing }\end{array}$} & & 89,0 & 89,8 & 9,8 & 9,2 & 1,4 & 1,0 \\
\hline & & 30,5 & 49,3 & 40,0 & 38,0 & 28,9 & 12,7 \\
\hline
\end{tabular}

Legend: E.gr. -experimental groups; K. gr. - control groups

These tables allow us to conclude that the level of readiness for designing a humanistically oriented educational environment of the university among the teachers of the experimental groups significantly increased at the final stage compared to the initial, while in the control group these changes were less significant

\section{The discussion of the results}

For our study, it is important to change constructs in the direction of cognitive complexity, reduction of fixed stereotypes, and a more adequate assessment of oneself, correlating with creativity. The expansion of semantic boundaries with their non-rigid assignment allows us to talk about self-awareness and awareness of professional goals, and the formation of the "Self-real" as a free, creative person with the assumption of responsibility. The degree of subjective affinity of the "I-real" is determined by one of the proposed constructs - "The happiest person". The three studied constructs are focused on success, social approval and self-realization. In this context, identification with the happiest person indicates an increase in orientation and self-actualization, that is, to the highest level of values. These changes, in conjunction with the information and organizational work done, have revealed the need to set the goal of developing a humanistic personal position with a focus on higher values. So:

1. The conducted set of classes in the form of organized training has a positive impact on the dynamics of professional self-awareness and personal characteristics of teachers.

2. In the process of classes, teachers assess their professionally important qualities more adequately, to a large extent revealing the potential of their "I" and the possibilities of their self-realization.

3. In the process of learning with the use of methods of self-control and self-regulation, the development of the behavioral component of the professional self-esteem of specialists is stimulated. 
The results of the studies indicate the need to identify the parameters of the readiness of teachers to design a humanistically oriented educational environment, which involves information and organizational training, the ability to design an educational environment, as well as the personal formation of such components of the "Self-concept" as creativity, intentionality, authenticity, and desire to self-actualization.

\section{Conclusion}

Thus, such integral personal qualities as authenticity and intentionality were decisive in the action of the internalization mechanism and the formation of a stable "Self-concept" oriented in the structure of the "Self-real" towards higher values. In the formative experiment, these qualities were developed to the optimum level. The systems of personality constructs, which at the final stage of the experiment were characterized by less polar assignment and greater cognitive complexity, testified to the expansion of semantic boundaries and awareness of the subjective significance of higher values. Highest values, according to our research objectives, occupy a dominant position in the structure of professionally important psychological qualities of a specialist. The study of personality characteristics allowed us to determine the "vector" of personality development - the acceptance of the values of others and our "Self" - values of creativity, freedom of choice, responsibility - values of self-actualization. This vector of development has determined the path of self-improvement and personal growth.

\section{References}

1. YU.G. Abramova, Lichnost' i predmetno-prostranstvennaya sreda, 120-131 (2000)

2. V.A. Kozyrev, Pedagogicheskiy universitet kak istochnik obrazovatel'nykh innovatsiy v vysshem pedagogicheskom obrazovanii (Izd-vo RGPU im. A. I. Gertsena, St. Petersburg, 2005)

3. Y.U. Kulyutkin, S. Tarasov, Novyye znaniya, 1, 6-7 (2001)

4. I.V. Abakumova, L.TS. Kagermazova, P.N. Yermakov, Tekhnologii napravlennoy translyatsii smyslov $v$ praktike uchebnogo protsessa (CREDO, Moscow, 2016)

5. Ye.B. Laktionova, Izvestiya Rossiyskogo gosudarstvennogo pedagogicheskogo un-ta im. A.I.Gertsena. 128, 40-54 (2010)

6. V.I. Slobodchikov, S.M. Zverev, Klyuchevyye kategorii myshleniya professional'nogo pedagoga : vvedeniye v antropologiyu obrazovaniya (Sputnik, Moscow, 2013)

7. S.V. Tarasov, Vestnik Leningradskogo gos.un-ta im.A.S.Pushkina, 3, 133-138 (2011)

8. A.S. Berberyan, H.S. Berberyan, Voprosy psikhologii, 1, 103-115 (2017)

9. A.S. Berberyan, Psikhologiya vysshego obrazovaniya $v$ kontekste gumanizatsii («Sociosfera-CZ», Praga, 2014)

10. Carl Rogers: Student-Centered Learning (1996)

11. V. Frankl, On the theory and therapy of mental disorders: An introduction to logotherapy and existential analysis (Brunner-Routledge, New York, 2004)

12. G.A. Kelly, The psychology of personal constructs (Norton, New York, 1955)

13. Future visions: The unpublished papers of Abraham Maslow (Sage, Thousand Oaks, 1996)

14. D.A. Leont'yev, Psikhologiya smysla: priroda, stroyeniye $i$ dinamika smyslovoy real'nosti (Smysl, Moscow, 1999) 